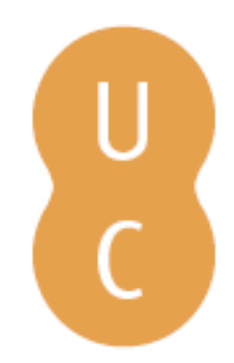

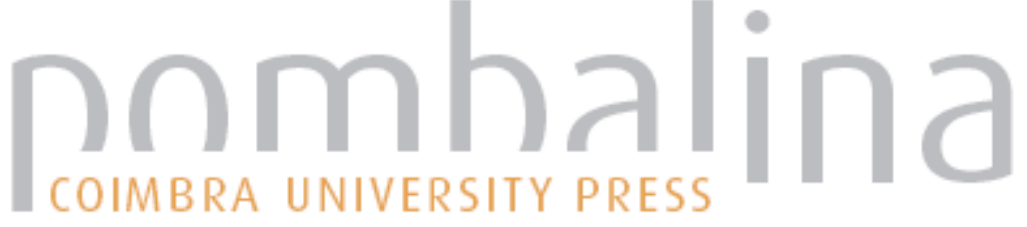

\section{Extreme climatic periods in Eastern Slovakia lowlands}

\begin{tabular}{ll} 
Autor(es): & $\begin{array}{l}\text { Harbuáková, Vlasta Ondrejka; Zeleáková, Martina; Purcz, Pavol; Portela, } \\
\text { Maria Manuela; Hlavatá, Helena; Straarová, Michaela }\end{array}$ \\
Publicado por: & $\begin{array}{l}\text { Imprensa da Universidade de Coimbra; RISCOS - Associação } \\
\text { Portuguesa de Riscos, Prevenção e Segurança }\end{array}$ \\
$\begin{array}{ll}\text { URL } \\
\text { persistente: }\end{array}$ & URI:http://hdl.handle.net/10316.2/34844 \\
DOI: & DOI:http://dx.doi.org/10.14195/978-989-96253-3-4_46 \\
Accessed : & 26-Apr-2023 05:43:35 \\
\hline
\end{tabular}

A navegação consulta e descarregamento dos títulos inseridos nas Bibliotecas Digitais UC Digitalis, UC Pombalina e UC Impactum, pressupõem a aceitação plena e sem reservas dos Termos e Condições de Uso destas Bibliotecas Digitais, disponíveis em https://digitalis.uc.pt/pt-pt/termos.

Conforme exposto nos referidos Termos e Condições de Uso, o descarregamento de títulos de acesso restrito requer uma licença válida de autorização devendo o utilizador aceder ao(s) documento(s) a partir de um endereço de IP da instituição detentora da supramencionada licença.

Ao utilizador é apenas permitido o descarregamento para uso pessoal, pelo que o emprego do(s) título(s) descarregado(s) para outro fim, designadamente comercial, carece de autorização do respetivo autor ou editor da obra.

Na medida em que todas as obras da UC Digitalis se encontram protegidas pelo Código do Direito de Autor e Direitos Conexos e demais legislação aplicável, toda a cópia, parcial ou total, deste documento, nos casos em que é legalmente admitida, deverá conter ou fazer-se acompanhar por este aviso.

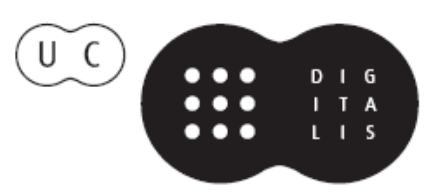



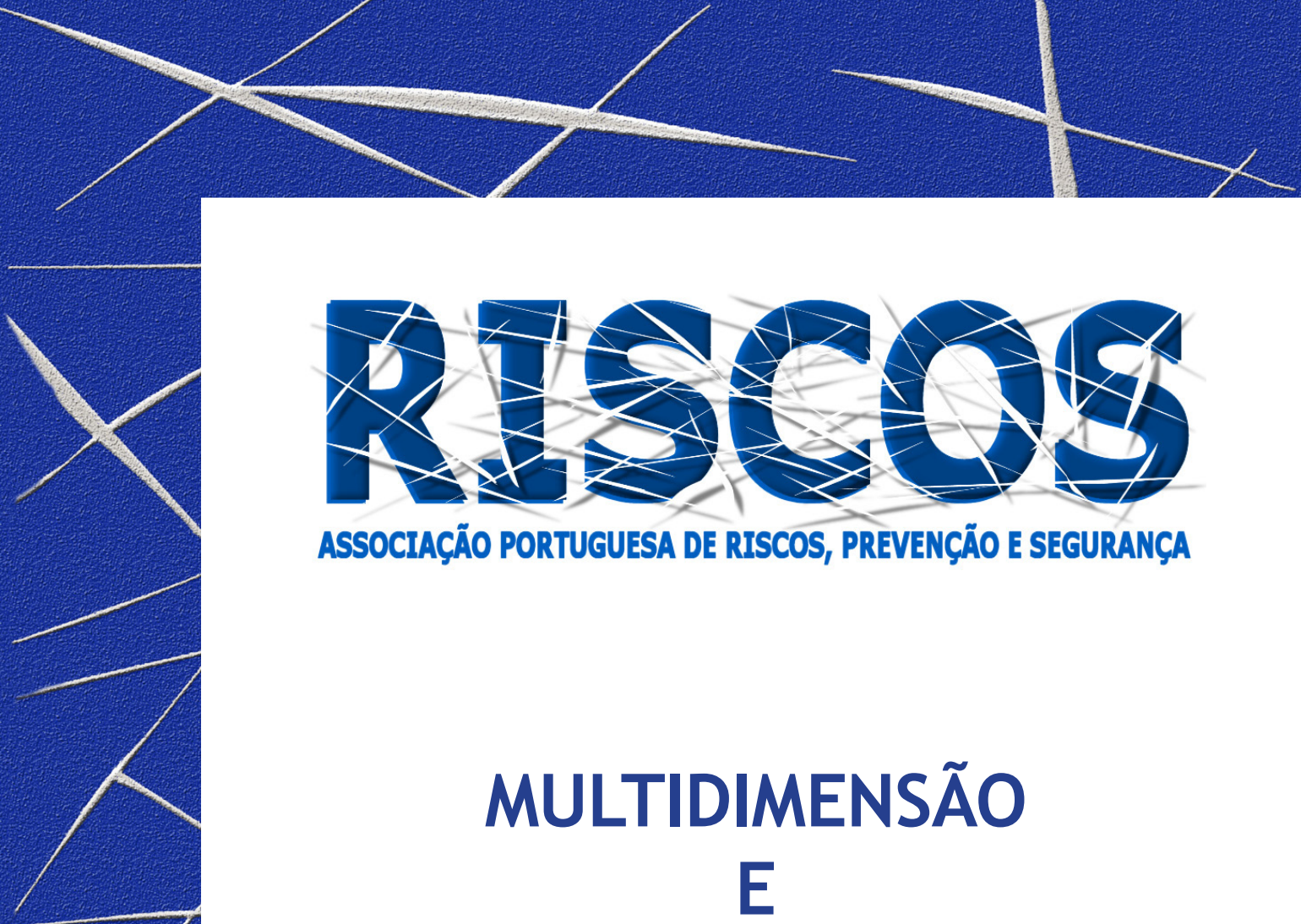

ASSOCIAÇÃO PORTUGUESA DE RISCOS, PREVENCCÃO E SEGURANÇA

MULTIDIMENSÃO

E
TERRITÓRIOS DE RISCO

III Congresso Internacional

I Simpósio Ibero-Americano

VIII Encontro Nacional de Riscos

Guimarães

2014 


\title{
EXTREME CLIMATIC PERIODS IN EASTERN SLOVAKIA LOWLANDS
}

\author{
Vlasta Ondrejka Harbuláková \\ Department of Environmental Engineering, Faculty of Civil Engineering of the Technical University of Košice \\ vlasta.harbulakova@tuke.sk \\ Martina Zeleňáková \\ Department of Environmental Engineering, Faculty of Civil Engineering of the Technical University of Košice \\ martina.zelenakova@tuke.sk \\ Pavol Purcz \\ Department of Mathematics, Faculty of Civil Engineering of the Technical University of Košice \\ pavol.purcz@tuke.sk \\ Maria Manuela Portela \\ Department of Civil Engineering, Architecture and Geo Resources, Technical University of Lisbon \\ maria.manuela.portela@ist.utl.pt \\ Helena Hlavatá \\ Slovak Hydrometeorological Institute \\ helena.hlavata@shmu.sk \\ Michaela Stračarová \\ Department of Environmental Engineering, Faculty of Civil Engineering of the Technical University of Košice \\ michaela.stracarova@tuke.sk
}

\begin{abstract}
The climate-induced natural disasters and occurrence of extraordinary weather events caused serious problems in many countries of the world. Changes in precipitation lead to changes in runoff and water availability. Intergovernmental panel on climate change states that runoff is projected with high confidence to increase by 10 to $40 \%$ by mid-century at higher latitudes and decrease by 10 to $30 \%$ over some dry regions at mid-latitudes due to decrease in rainfall and higher rates of evapotranspiration. The objective of this paper is to analyze variability of long-term precipitation data series over the last 30 years for climatic stations in Slovakia lowlands situated in the east of the country. Statistics of precipitation extremes, extraordinary summer rainfall event, and occurrence of wet and dry periods in different zones of special altitudinal profile in approximately 110 meters above the sea level are presented in this work.

Keywords: dry period, wet period, hydrological extremes.
\end{abstract}

\section{Introduction}

Interactions between land and atmosphere are of fundamental importance for hydrological cycle. Climate and weather drive precipitation development in the atmosphere, while the landscape features determine distribution of water on the land surface. There are evidences of the impact of human activities and climate on changing hydrological cycle, including the observed large-scale patterns of precipitation changes over the $20^{\text {th }}$ century (e.g. IPCC, 2012). Variability of weather causes different substitution of dry and wet periods, e.g. groups of days, months, seasons or years (Paulson et al., 1985). Knowing the probability of occurrence of each period has extraordinary economic importance, especially in relation to other climatic factors, e.g. the temperatures. Data on the incidence and duration of dry and wet periods are expressed usually by statistical methods and the results are subjected to analysis. Scientists are trying to discover in substitution of dry and wet periods the regularity or periodicity (Parajka et al., 2009). Most often they are looking for relationship with 11 -year period of sunspots (Pekárová et 
al., 2008). Other times the shorter periods - 3, 7, 8 years are used. Find regularity of these changes and use it successfully is still the task of research.

The paper is devoted to analysis of extreme climatic periods in south eastern part of Slovakia particularly to analysis of wet and dry period's occurrence in two climatic stations Humenné and Michalovce.

\section{Material and methods}

Climatic data series - daily amount of precipitation were provided by the Slovak Hydrometeorological Institute (SHMI). We evaluated the data during 31 years from 1980 to 2011, separately for five periods: 1980; 1981-1990; 1991-2000; 2001-2010; 2011. The aim of the study was to analyse precipitation data with result to determine the duration of dry and wet periods in the evaluated climatic stations.

Drought is considered for purposes of this study as the number of consecutive days without precipitation. Wet is the number of consecutive days with precipitation greater than $0.1 \mathrm{~mm}$. Duration of dry and wet periods is divided into the following categories:

- KD - short-term wet / dry period of a length in the range 1 to 5 days,

- SD - medium-term wet / dry period with duration of between 6-10 days,

- DD - long-term wet / dry period with duration of 11 days or more.

For each climatic station we have subsequently processed analysis of dry and wet periods, which contain the sum of the individual categories KD, SD or DD and graphs of the absolute value of dry and wet periods.

\section{Results}

In climatic station Humenné (in $148 \mathrm{~m}$ asl.) we observed the longest dry period in 2005 which lasted 37 days. The decade from 2001 to 2010 was the driest - totally 34 long-term dry periods occurred in that time. The longest wet period lasted 17 days and occurred in 1991. The wettest was the decade from 1991 to 2000 and four long-term periods occurred in that decade in Humenné.

Figure 1 presents course of absolute dry periods and Figure 2 presents course of absolute wet short-term, medium-term, long-term periods for duration from 1980-2011 separately for five temporal (decadal) periods in climatic station Humenné. 


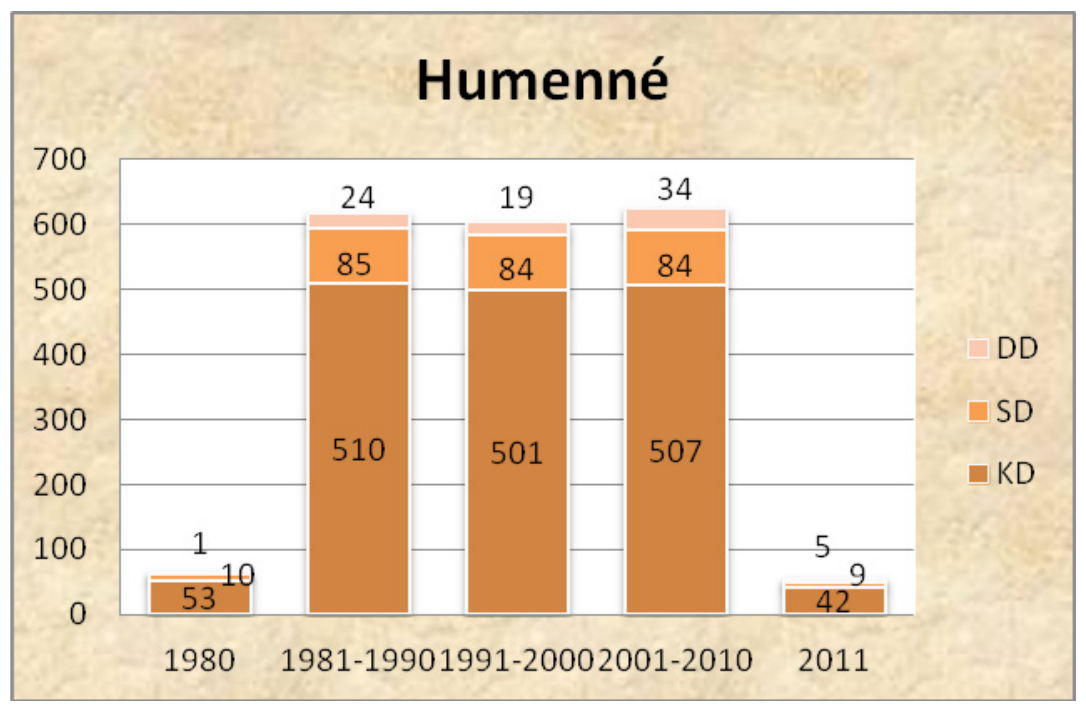

Figure 1 Ten-year courses of absolute frequency of dry periods in Humenné

Total sum of short-term drought was 1613 periods, medium-term drought was 272 periods, and long-term dry periods occurred 83 times. Figure 1 also shows the absolute number of dry periods observed at this station from 1980 to 2011 was 1968.

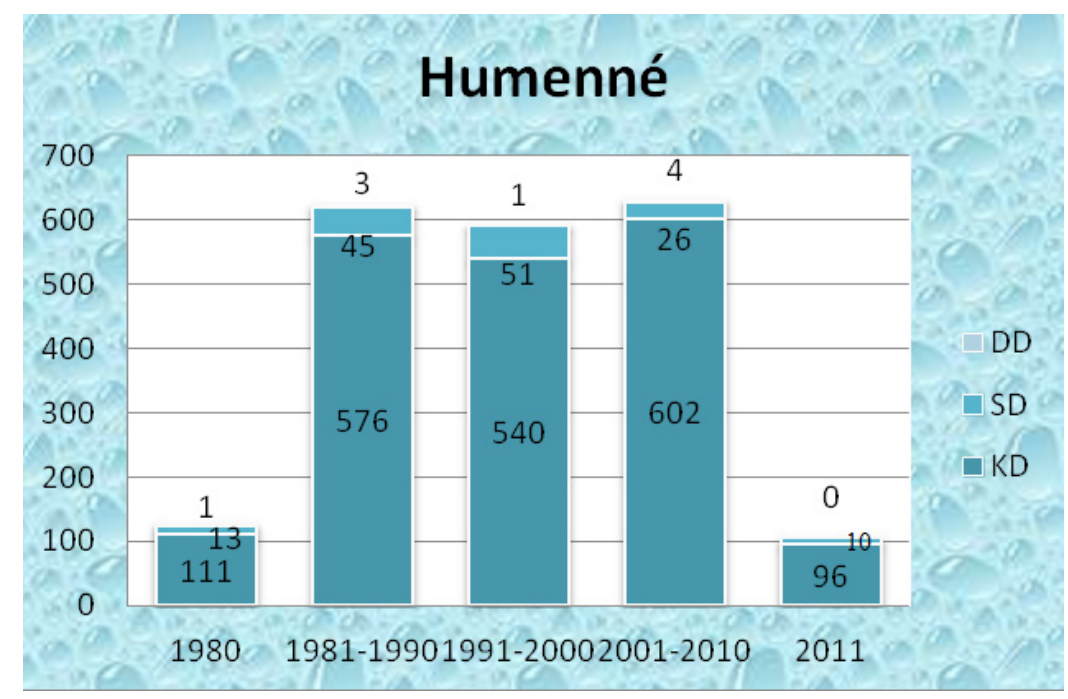

Figure 2 Ten-year courses of absolute frequency of wet periods in Humenné 
The total sum of the short wet period was 1925, the number of medium-term wet periods was 145 and long-term wet periods occurred 9 times. The Figure 2 also shows that the absolute number 2079 of wet terms was observed at this station.

Figure 3 presents course of absolute dry periods and Figure 4 presents course of absolute wet short-term, medium, long-term periods for duration from 1980-2011 separately for five temporal (decadal) periods in climatic station Michalovce.

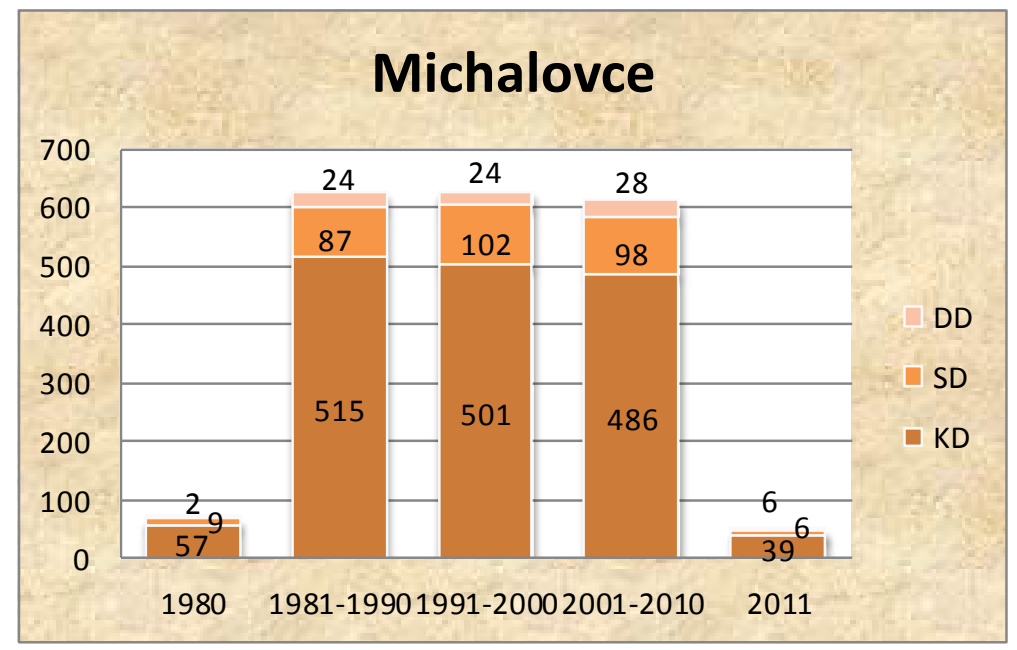

Figure 3 Ten-year courses of absolute frequency of dry periods in Michalovce

Total sum of short-term drought was 1598 days, medium-term drought was 302 days and the long-term drought occurred in 84 days. The Figure 3 shows that the absolute number of dry days measured at Michalovce climatic station over the evaluated period was 1984.

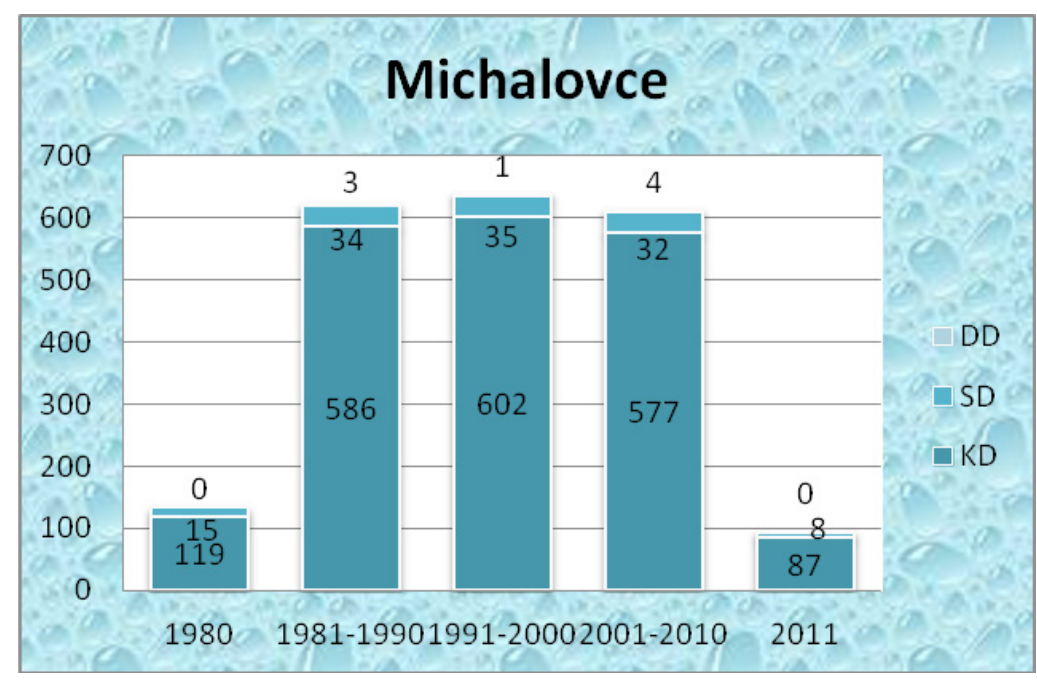

Figure 4 Ten-year courses of absolute frequency of wet periods in Michalovce 
The total sum of the short-term wet period was 1971, medium-term wet periods occurred 124 times and long-term wet period occurred 8 times. The Figure 4 also shows that the absolute number of wet periods observed at this station during evaluated years was 2104 .

In climatic station Michalovce (111 m asl.) the longest drought lasted for 36 consecutive days and this value was observed in 2011. Totally 28 long-term dry periods occurred in decade from 2001 to 2010, 24 long-term dry periods occurred in 1981-1990 as well as in 1991-2000. The longest wet period lasted 16 days and occurred in 1991. The wettest was the decade from 2001 to 2010 and four long-term wet periods occurred in that decade in Michalovce station.

\section{Conclusion}

The aim of our study is to emphasize the need for understanding and measuring precipitation, which most affect the level change in watercourses and following this the hydrological conditions in river basins. As we know from knowledge of the amount of precipitation that falls on a certain area for a certain period of time, we can determine for example the most likely area of occurrence of floods, and also the drought vulnerable areas that is concern mainly of agriculture. Reasonable rainwater management is inevitable for economy of the country.

The aim of presented analysis was to determine the course of dry and wet periods in evaluated climatic stations. It can be clearly seen that the medium and long term period with precipitation is very rare in Humenné station when we compare the results from evaluation of dry periods. The usual frequency of continuous wet period is one to three consecutive days with precipitation, which represents only a short-term wet. The frequency of long-term dry periods occurs more often than that of wet periods.

The driest years were 2005 and 2011 and the wettest was 1991 in the evaluated period and study area.

\section{Acknowledgments}

This work has been supported by the Slovak Research and Development Agency SK-PT-0001-12.

\section{Bibliography}

IPCC Working Group II: Impacts, Adaptation and Vulnerability. Extreme high temperature and precipitation events. (2012) - Available at: http://www.ipcc.ch/ipccreports/tar/wg2/index.php?idp=625

Parajka, J., Kohnová, S., Merz, R., Szolgay, J., Hlavčová, K., Blőschl, G. (2009) - Comparative analysis of the seasonality of hydrological characteriscs in Slovakia and Austria. Bratislava: SAV

Paulson, E., Sadeghipour, J., Dracup, J. A. (1985) - Regional frequency analysis of multiyear droughts using watershed and climatic information. Journal of Hydrology 77, p. 57-76.

Pekárová, P., Halmová, D., Miklánek, P., Pekár, J. (2008) - Analýza zmien N-ročných minimálnych prietokov rieky Dunaj v profile Bratislava za obdobie rokov 1876/77-2005/06. Bratislava: SAV.

Stračarová, M. (2014) - Hydrological extremes - dry and wet periods. Thesis. Košice: FCE. 